\title{
Kesabaran sebagai nilai kebajikan dan efeknya terhadap resiliensi: Peranan moderasi dari disposisi harapan
}

\author{
Fahrul Rozi* \& Anggun Prasasti \\ Fakultas Psikologi, Universitas Muhammadiyah Prof.Dr.HAMKA, Jakarta Selatan, DKI Jakarta
}

\begin{abstract}
Abstrak
Penelitian ini bertujuan untuk mengetahui peran disposisi harapan pada efek kesabaran terhadap resiliensi. Penelitian ini memprediksikan efek sabar terhadap resiliensi diperkuat dengan disposisi harapan yang tinggi. Terdapat 320 responden yang berpartisipasi dalam penelitian ini (52\% perempuan) dengan rata-rata usia 16,3 tahun $(S D=0,89)$. Hasil penelitian menunjukkan bahwa harapan memiliki peran yang signifikan sebagai moderator pada efek kesabaran terhadap resiliensi dan efek tersebut tergantung pada disposisi variabel harapan. Pada individu yang memiliki disposisi harapan yang tinggi, efek kesabaran terhadap resiliensi akan semakin kuat. Sedangkan, individu yang memiliki disposisi harapan yang rendah, efek kesabaran terhadap resiliensi menjadi tidak signifikan. Hasil penelitian ini membuktikan bahwa efek sabar terhadap resiliensi diperkuat dengan disposisi harapan yang tinggi.
\end{abstract}

Kata kunci: Harapan, sabar, resiliensi

\begin{abstract}
The current study is intended to determine the role of hope in the effect of patience on resilience. This study predicts effects are impatient with the resilience reinforced with high hope disposition. 320 respondents ( $52 \%$ female) participated in this study with an average age of 16.3 $(S D=0.89)$. The results of this study indicates that hope has a significant role as a moderator in the relationship between patience and resilience. In individuals who have high disposition of hope, the effects of patience to resilience will be stronger. Meanwhile, in individuals who have lower disposition of hope, the effects of patience to resilience becomes insignificant. The results of the study prove that the effect of patience on resilience is strengthened by the high disposition of hope.
\end{abstract}

Keywords: Resilience; patience; hope

\section{Pendahuluan}

Istilah resiliensi didefinisikan sebagai suatu kemampuan melakukan adaptasi yang positif dalam menghadapi peristiwa traumatis (Newman, 2005). Konsep ini menarik banyak peneliti untuk mengeksplorasi mengapa individu tidak menyerah ketika mengalami kesulitan dan termotivasi untuk menuju kesuksesan yang lebih besar. Telah banyak studi yang berupaya menjelaskan pembentukan resiliensi yang berasal dari karakteristik lingkungan dan karakteristik individu (Bonanno, Galea, Bucciarelli, \& Vlahov, 2007; Simeon, dkk., 2007). Pembentukan resiliensi dari karakteristik lingkungan tergambar dalam penelitian pada konteks kehidupan keluarga, di mana ayah dan sistem keluarga memainkan peran penting dalam meningkatkan pada remaja yang mengalami depresi (Mahedy, dkk., 2018) Sedangkan, pada konteks pendidikan siswa di sekolah, kelekatan sekolah yang aman terbukti dapat meningkatkan resiliensi (Oldfield, Stevenson, Ortiz, Haley, 2018).

Pembentukan resiliensi dari karakteristik individu, menunjukkan korelasi yang positif antara resiliensi dengan harapan hidup (Jenaabadi \& Mir, 2019), kesehatan mental (Hu, Zhang, \& Wang, 2015) dan religiusitas (Al Eid, dkk., 2020). Resiliensi bukan hanya dibentuk dari konteks karakteristik individu yang bersifat tetap, akan tetapi dapat juga dikembangkan dan dibingkai oleh nilai-nilai kebajikan (Kim, dkk., 2018). Ada banyak nilai kebajikan yang bersifat universal yang perlu dipertimbangkan dalam proses pembentukan resiliensi. Namun, nilainilai kebajikan yang diajukan pada kajian terkini belum menyentuh aspek kesabaran yang merupakan salah satu bagian dari nilai kebajikan (Clanton, dkk., 2014).

Penelitian terkini telah menjelaskan pembentukan resiliensi berasal dari perspektif nilai kebajikan (Kim, dkk., 2018). Penelitian tersebut berupaya menjawab tantangan yang mene- 
kankan perlu adanya konsep kritis untuk menjelaskan resiliensi secara lebih komprehensif. Tantangan selanjutnya, demi meningkatkan kajian resiliensi dari perspektif nilai kebajikan, maka perlu adanya penelitian yang mengeksplorasi aspek kesabaran dengan mempertimbangkan variabel harapan sebagai penguat efek antar variabel tersebut. Artikel ini mengajukan perspektif baru yang berusaha mengungkap efek nilai kebajikan pada kesabaran terhadap resiliensi dengan mempertimbangkan peran moderasi dari disposisi harapan yang tinggi.

Berdasarkan kajian-kajian tentang resiliensi dan kesabaran, menunjukkan bahwa antar variabel tersebut memiliki keterkaitan. Hal ini dapat dilihat dari konsep yang diajukan oleh El Hafiz, Mundzir, Rozi, dan Pratiwi (2015), di mana kesabaran diartikan sebagai respon awal yang aktif dalam menahan emosi, pikiran, perkataan, dan perbuatan disertai semangat mencari solusi, konsisten, berorientasi pada tujuan yang baik dan tidak mengeluh. Pada definisi lain, sabar diartikan sebagai kemampuan untuk menahan diri untuk tidak berkeluh-kesah, mencegah lisan untuk merintih dan menghalangi anggota tubuh untuk melakukan tindakan yang merusak diri (Al-Jauziyah \& Ibn, 2006). Individu yang sabar dapat mengontrol dirinya untuk tangguh dalam menghadapi permasalahan, tidak mudah menyerah ketika menghadapi situasi sulit, dan berorientasi pada tujuan (Ong, Standiford, \& Dishpande, 2017). Tanpa adanya tujuan, perilaku resiliensi tidak akan pernah muncul pada diri individu (Brooks \& Goldstein, 2009).

Kemampuan mengontrol diri yang ditunjukkan oleh individu yang sabar, memperkuat keterkaitan antara kesabaran dengan resiliensi. Kontrol diri menjembatani keterkaitan antara kesabaran dengan resiliensi secara teoritis. Keterkaitan tersebut terletak pada kesesuaian konsep antara kontrol diri dengan kesabaran (Subandi, 2011; Usman, 2016). Kontrol diri juga merupakan salah satu komponen dari resiliensi (Connor \& Davidson, 2003), dan termasuk bagian yang tak terpisahkan dari resiliensi (Brooks \& Goldstein, 2009).

Lebih lanjut, sebuah penelitian eksperimental yang dilakukan oleh Maslahah (2011) menunjukkan bahwa pelatihan sabar dianggap efektif dalam meningkatkan resiliensi. Individu yang memiliki kesabaran akan terus berupaya menahan diri untuk tidak melenceng dari proses pencapaian tujuan dan mencari pemecahan masalah tanpa berkeluh kesah (El Hafiz, Mundzir, Rozi, \& Pratiwi, 2015) yang meliputi aspek kognitif, perilaku dan emosi (Brockhoff, Margolin, \& Weber, 2015) Individu yang sabar akan memiliki kemampuan dalam memecahkan masalah sehingga dapat menghadapi dan memulihkan diri dari situasi stress atau trauma (Iacoviello \& Charney, 2019).

Studi kualitatif telah menjelaskan bahwa kesabaran merupakan faktor penting dalam pembentukan resiliensi (Hassani, Izani-Avanji, Rakhshan, \& Majd, 2017). Penelitian tersebut mendeskripsikan kesabaran dan kepercayaan kepada Tuhan dapat dijadikan strategi coping untuk menurunkan kecemasan dan berfungsi meningkatkan harapan serta saling melengkapi dalam mempengaruhi suatu variabel (Bajaj \& Pande, 2016). Walaupun minim penelitian yang mengkaitkan antara kesabaran dengan resiliens konstruk kesabaran memberikan konsep yang mendasar dan fundamental dalam memahami resiliensi.

Penelitian dan kajian teoritis tentang kesabaran dan resiliensi telah terbukti memiliki keterkaitan. Namun, kajian tersebut belum mempertimbangkan harapan dalam interaksi efek kesabaran terhadap resiliensi. Keterhubungan antara kesabaran dengan resiliensi akan memberikan pengembangan eksplorasi yang mendalam tentang resiliensi itu sendiri. Menurut Grotberg (1995), perbedaan tingkat resiliensi ini dipengaruhi salah satunya oleh harapan yang termasuk dalam faktor internal dalam diri yang disebut sebagai I am. Hal ini didukung oleh penelitian yang telah dilakukan oleh Solano, Da Silva, Soares, Ashmawi, dan Vieira (2016) yang membuktikan bahwa terdapat korelasi signifikan antara harapan dengan resiliensi. Harapan inilah yang memunculkan motivasi yang positif untuk sukses mencapai tujuan dan berupaya untuk merencanakan secara matang demi tercapainya tujuan yang diinginkan (Ong, Standiford, \& Dishpande, 2017).

Di sisi lain, Brooks dan Goldstein (2009) beranggapan bahwa individu yang tidak memiliki tujuan hidup akan mengalami kesulitan dalam mencapai pribadi yang resilien. Tujuan akan menuntun seseorang untuk memiliki komitmen, antusiasme dan makna hidup sehingga terdorong untuk memiliki kemampuan dalam mengurangi dampak stres pada kehidupannya. Harapan akan mendorong individu lebih siap untuk menghadapi situasi sulit sebagai konsekuensi atas tujuan yang ditetapkannya, sehingga ia lebih mampu untuk mengatasi stress secara lebih efektif. Sebagaimana diungkapkan Snyder (2000), individu dengan harapan tinggi justru menetapkan tujuan yang lebih sulit.

Sebuah penelitian yang dilakukan oleh Rahimipour, Shahgholian, dan Yazdani (2015) menunjukkan bahwa terjadi penurunan skor depresi, kecemasaan, dan stres yang signifikan pada responden setelah menjalani terapi harapan. Semakin tinggi harapan, maka akan semakin 
rendah kemungkinan untuk mengalami depresi. Selain itu, individu dengan harapan yang tinggi juga memiliki kecenderungan untuk berpikir lebih positif terhadap situasi sulit yang memicu stres, dibandingkan individu yang memiliki harapan yang rendah.

Hubungan yang kuat antara harapan dengan resiliensi yang telah dibuktikan dalam beberapa penelitian (Li, Yang, Liu, \& Wang, 2016; Solano dkk., 2016). Hal ini mendorong anggapan bahwa harapan memegang peranan penting dalam menentukan efek suatu variabel terhadap terbentuknya resiliensi, yang disebut sebagai efek moderator. Peran harapan sebagai variabel moderator pada hubungan antar-variabel telah dibuktikan pada sebuah penelitian tentang gangguan fungsional dan gejala depresi yang dimoderasi oleh disposisi variabel harapan (Hirsch, Sirois, \& Lyness, 2011).

Peran harapan sebagai moderator pada efek kesabaran terhadap resiliensi juga dapat dilihat dari unsur yang dimiliki harapan, yaitu semangat atau motivasi dan kayakinan untuk mencapai tujuan. Semangat dan motivasi yang menjadi unsur harapan dipercaya dapat meningkatkan efek kesabaran terhadap resiliensi. Harapan merefleksikan kemampuan untuk menghasilkan berbagai alternatif cara untuk mencapai tujuan yang diiringi dengan motivasi (Lopez \& Snyder, 2003).

Interaksi antara kesabaran dengan harapan terletak pada konsep motivasi untuk mencapai tujuan. Individu yang sabar akan berupaya meningkatkan motivasi untuk mencapai tujuan yang baik (El Hafiz, Mundzir, Rozi, \& Pratiwi, 2015). Motivasi untuk mencari solusi yang ditunjukkan oleh individu yang sabar akan diperkuat dengan keyakinan untuk mencapai tujuan. Harapan akan memberikan keyakinan kepada individu untuk mencapai tujuan yang telah ditetapkan (Faith, Mayes, Pratt, \& Carter, 2019; Nelissen, 2017).

Individu yang sabar memiliki motivasi untuk mendorong dirinya mencapai tujuan. Motivasi dalam mencapai tujuan inilah yang akan mendorong individu untuk meningkatkan harapan (Nelissen, 2017). Individu yang memiliki harapan yang tinggi akan lebih siap untuk menghadapi situasi sulit dan termotivasi untuk mencapai tujuan dengan berbagai macam cara (Cheavens \& Ritschel, 2014). Harapan yang tinggi lebih mendorong individu untuk menetapkan tujuan yang lebih sulit, jika dibandingkan dengan individu yang memiliki harapan yang rendah. Individu dengan harapan yang tinggi lebih mungkin untuk menghadapi situasi yang sulit, karena pandangan positif mereka terhadap kesulitan membuat mereka dapat menghadapi stres dengan lebih baik (Rahimipour, Shahgholian, dan Yazdani, 2015).

Dengan demikian, individu sabar yang memiliki harapan yang tinggi dapat melihat kesulitan dari sisi yang lebih positif sebagai suatu tantangan dan menjadikanya sebagai sumber belajar, dibandingkan jika individu menjadikan situasi tersebut sebagai alasan untuk merasa kalah. Individu yang tahan stres lebih melihat kesulitan sebagai sebuah tantangan yang mengandung arti optimisme dan orientasi terhadap pemecahan masalah (Brooks \& Goldstein, 2009). Individu dengan harapan yang tinggi tidak menunjukkan keputusasaan dalam menghadapi situasi sulit. Akan tetapi, merasa tertantang dan menunjukkan kemampuan untuk mengembangkan dirinya dalam kesulitan tersebut demi tercapainya suatu tujuan.

Begitu pentingnya disposisi harapan yang tinggi dalam meningkatkan efek sabar terhadap resiliensi, menunjukkan bahwa unsur kemampuan menentukan cara dan keyakinan yang kuat bahwa individu mampu mencapai tujuan (Snyder, 2000), dapat menjadi penentu pada saat individu memiliki kesabaran yang berefek terhadap memunculkan resiliensi. Disposisi harapan yang tinggi menjadi prediktor yang kuat dalam menentukan kekuatan efek sabar terhadap resiliensi.

Selanjutnya, untuk dapat memahami efek kesabaran terhadap resiliensi, peneliti menduga bahwa kekuatan efek antarvariabel tersebut, bergantung pada disposisi harapan yang tinggi. Hipotesis yang diajukan dalam penelitian ini adalah efek kesabaran terhadap resiliensi diperkuat dalam kondisi disposisi harapan yang tinggi.

\section{Metode Penelitian}

\section{Partisipan}

Penelitian ini dilakukan di SMA (Sekolah Menengah Atas) XYZ di Wilayah Jakarta. Partisipan yang ikutserta dalam penelitian ini berjumlah 320 siswa. Teknik yang digunakan dalam pengambilan sampling adalah cluster random sampling. Berdasarkan data dari 320 siswa yang mengisi kuesioner, sebanyak $52 \%$ berjenis kelamin perempuan dan rata-rata usia sebesar 16,3 tahun $(\mathrm{SD}=0,89)$.

\section{Prosedur}

Pengambilan data partisipan dalam penelitian ini didahului dengan pengajuan permohonan izin kepada pihak sekolah SMA XYZ. Setelah mendapatkan izin dari pihak sekolah, peneliti menjelaskan kepada partisipan tentang 
tujuan penelitian, perlakuan yang diterapkan pada partisipan berupa pemberian kuesioner, dan waktu yang dibutuhkan untuk pengisian kuesioner. Setelah mendapatkan persetujuan, peneliti memberikan lembaran informed consent yang akan ditandatangani oleh partisipan. Setelah mentandatangani informed consent, partisipan mengisi kuesioner penelitian yang telah disediakan. Penyebaran kuesioner penelitian ini membutuhkan waktu dua hari kerja.

\section{Alat Ukur}

\section{Skala Harapan.}

Untuk mengukur variabel harapan, digunakan Adult Dispotitional Hope Scale (ADHS) yang dikembangkan oleh Snyder (2000) dan telah dikaji secara psikometri oleh Pacico, Bastianello, Zanon, Hutz (2013) untuk dilakukan proses validasi yang bertujuan agar ADHS dapat digunakan pada partisipan remaja. Analisis faktorial dengan rotasi varimax yang digunakan oleh Pacico dkk. (2013) menunjukkan bahwa skala ADHS memiliki unidimensionalitas dan konsistensi internal yang memadai (Cronbach's alpha $=0,80)$. Pada pernyataan item, ADHS tersebar dalam 12 item dengan 4 item sebagai distraktor yang berfungsi sebagai pengacau dan tidak dianalisis, dan 8 item bersifat favourable. Skala ini terdiri dari dua dimensi dengan masingmasing memiliki 4 item pada setiap dimensinya, yaitu dimensi pathways dan agency. Skala ini menggunakan rating scale dengan 8 kategori respon, diawali dengan angka 1 untuk "sangat tidak sesuai" sampai angka 8 untuk "sangat sesuai". Salah satu contoh pernyataan item pada dimensi pathways yaitu "Saya dapat memikirkan banyak cara untuk mengatasi hambatan", dan contoh item dari dimensi agency yaitu "Saya penuh semangat dalam mengejar tujuan hidup saya". Internal konsistensi (alpha-cronbach) yang didapatkan dari hasil penelitian ini sebesar $0,849(\alpha=.849)$.

\section{Skala Kesabaran.}

Variabel kesabaran diukur dengan menggunakan skala kesabaran (El Hafiz, Mundzir, Rozi, \& Pratiwi, 2015) dengan nilai reliabilitas 0,830 yang termasuk dalam kategori reliabilitas yang tinggi berdasarkan kaidah Guilford. Skala ini terdiri dari 20 item dengan 5 item sebagai distraktor yang tidak dianalisis, 8 item favorabel dan 7 item unfavorabel. Skala ini menggunakan skala likert dengan 4 kategori respon yaitu Sangat Sesuai (SS), Sesuai (S), Tidak Sesuai (TS), Sangat Tidak Sesuai (STS). Skala ini terdiri dari 6 aspek yaitu optimis, pantang menyerah, konsisten, tidak mengeluh, memaafkan dan mencari ilmu untuk mendapatkan alternatif solusi. Sebelum merespon item, terlebih dahulu partisipan membaca kasus. Terdapat 4 kasus dengan masing-masing kasus memiliki 5 item, 1 kasus sebagai distraktor yang tidak dianalisis. Contoh kasus pada skala ini yaitu "Setelah mengalami kegagalan lebih dari sekali dalam upaya mencapai tujuan yang baik, saya diharuskan mengulang prosesnya dari awal. Reaksi pertama saya adalah...". Sedangkan contoh item pada pada kasus tersebut yaitu "Saya mendiskusikan cara untuk mencapai tujuan dengan orang yang telah berhasil". Skala ini memiliki internal konsistensi (alpha-cronbach) sebesar 0,875 ( $\alpha=.875)$.

\section{Skala Resiliensi.}

Untuk mengukur resiliensi digunakan Connor-Davidson Resilience Scale (CD-RISC) yang telah diadaptasi ke dalam Bahasa Indonesia oleh (Azzahra, 2017) dengan nilai reliabilitas 0,83 yang termasuk dalam kategori reliabilitas yang tinggi berdasarkan kaidah Guilford. Skala ini terdiri dari 25 item favorabel dan menggunakan jenis rating scale dengan 4 kategori respon, yaitu Tidak Terjadi (TT), Jarang Terjadi (JT), Sering Terjadi (ST), Selalu Terjadi (SLT). Contoh pernyataan item pada skala ini yaitu "Saya penuh semangat dalam mengejar tujuan hidup saya" dan "Saya memiliki banyak cara dalam menyelesaikan setiap masalah". Internal konsistensi (alphacronbach) yang didapatkan dari hasil penelitian ini sebesar 0,882 ( $\alpha=.882)$.

\section{Analisis Data}

Penelitian ini memiliki tiga variabel yang terdiri dari variabel kesabaran yang berfungsi sebagai Independen Variabel (IV), variabel resiliensi sebagai Dependen Variabel (DV), dan variabel harapan sebagai Variabel Moderator (M). Moderator adalah variabel yang menentukan kondisi pada efek IV terhadap DV. Moderasi mengandung efek interaksi yang dapat mengubah efek (arah hubungan) atau memperkecil atau memperbesar efek antara IV dan DV. Dalam analisis statistik moderasi, peneliti menggunakan PROCESS SPSS yang telah dikembangkan oleh Andrew F. Hayes (2013) dengan analisis model 1.

\section{Hasil Penelitian}

Uji Multikolinieritas pada Variabel Kesabaran dan Resiliensi 
Uji multikolinieritas dilakukan untuk menguji interkorelasi yang tinggi di antara variabel independen dalam model regresi berganda (Perez-Melo \& Kibria, 2020). Uji ini bertujuan membuktikan bahwa variabel kesabaran dan resiliensi bukanlah variabel yang sama dengan menunjukkan interkorelasi yang rendah antar variabel tersebut. Indikator yang digunakan untuk menguji multikolinieritas pada penelitian ini yaitu tolerance level dan Variance Inflation Factor (VIF). Berdasarkan uji multikolinieritas didapatkan koefisien tolerance level sebesar 0,845 (tolerance level $>0,4$ ) dan koefisien VIF sebesar 1,183 (VIF<2,5) pada variabel kesabaran dan resiliensi. Hal ini menunjukkan bahwa variabel kesabaran dan resiliensi bukanlah variabel yang sama.

\section{Peran Moderator Harapan Signifikan pada Efek Kesabaran terhadap Resiliensi.}

Analisis statistik yang digunakan dalam penelitian ini adalah moderasi model 1 yang dikembangkan oleh Hayes (2013), yang bertujuan mendeskripsikan peran moderator harapan (M) pada efek kesabaran (IV) terhadap resiliensi (DV). Analisis model 1 menjelaskan tentang efek moderator harapan pada efek kesabaran terhadap resiliensi. Kekuatan efek kesabaran terhadap resiliensi tergantung dari disposisi harapan.

Berdasarkan data yang didapatkan menunjukkan bahwa peran disposisi harapan memiliki efek interaksi pada kesabaran terhadap resiliensi. Kekuatan efek kesabaran terhadap resiliensi bervariasi, bergantung pada disposisi harapan. Hasil analisis statistik model 1 (dapat dilihat pada Tabel 1) menunjukkan bahwa adanya peran harapan, sebagai variabel moderator, signifikan dalam memperkuat efek kesabaran terhadap resiliensi. Koefisien interaksi yang didapatkan dari hasil analisis sebesar 0,0499 dan nilai $t=2,5833(\mathrm{p}<0,01)$. Penelitian ini juga membuktikan bahwa kesabaran dan harapan berefek positif signifikan terhadap resiliensi.

\section{Kekuatan efek kesabaran terhadap resiliensi tergantung pada disposisi harapan.}

Setelah mengetahui bahwa variabel harapan signifikan sebagai moderator pada efek kesabaran terhadap resiliensi, analisis selanjutnya adalah menguji disposisi harapan pada efek dua variabel tersebut. Berdasarkan hasil analisis menunjukkan bahwa peningkatan kekuatan efek kesabaran terhadap resiliensi tergantung pada disposisi harapan sedang dan tinggi, dibanding dengan disposisi harapan yang rendah. Data tercakup pada Tabel 2.

Berdasarkan Gambar 1 dan data pada Tabel 3, disposisi harapan yang rendah memberikan efek tidak signifikan terhadap asosiasi antara kesabaran dengan resiliensi. Ditemukan koefisien sebesar 0,0046 dan nilai $t$ sebesar $0,0001(p>0,05)$. Disposisi harapan sedang memberikan efek positif signifikan, dengan koefisien sebesar 0,3544 dan nilai $t$ sebesar 2,4296 $(\mathrm{p}<0,05)$, dengan memperkuat efek kesabaran terhadap resiliensi. Sedangkan, harapan tingkat tinggi memberikan efek positif pada efek kesabaran terhadap resiliensi yang signifikan, dengan koefisien sebesar 0,7042 dan nilai $t$ sebesar $3,9975(\mathrm{p}<0.01)$,

Analisis moderasi model 1 menunjukkan bahwa disposisi harapan dapat memperkuat efek kesabaran terhadap resiliensi menjadi berbeda. Individu yang sabar akan menghasilkan perilaku resiliensi tergantung pada perbedaan disposisi harapan (M). Peran sabar untuk munculkan perilaku resilien lebih besar ketika individu memiliki disposisi harapan yang tinggi dan sedang, dibandingkan individu dengan disposis harapan yang rendah. Meskipun disposisi harapan sama-sama menguatkan peranan sabar terhadap resiliensi, disposisi harapan tinggi dan sedang lebih besar memperkuat efek kesabaran terhadap resiliensi dibandingkan disposisi harapan yang rendah.

Di antara individu yang memiliki harapan yang tinggi $\left(\mathrm{H}_{\mathrm{High}}\right)$ dan sedang ( $\left.\mathrm{H}_{\text {Mean }}\right)$, memiliki kecenderungan semakin kuatnya efek kesabaran terhadap resiliensi. Namun, individu yang memiliki harapan yang rendah (HLow), peningkatan kekuatan efek kesabaran terhadap resiliensi menjadi tidak signifikan. Hal ini menunjukan bahwa moderator harapan memiliki fungsi sebagai peningkat, di mana peningkatan variabel moderator harapan akan memperkuat efek sabar terhadap resiliensi. Dengan kata lain, sabar memiliki efek yang signifikan terhadap resiliensi tergantung pada tinggi rendahnya disposisi harapan yang dimiliki oleh individu. Jika individu memiliki harapan yang tinggi dan sedang, maka sabar akan semakin kuat memunculkan resiliensi. Akan tetapi, jika individu memiliki harapan yang rendah tidak signifikan dalam memperkuat efek kesabaran terhadap resiliensi.

Penelitian ini menunjukkan bahwa sabar dapat meningkatkan kecenderungan resiliensi lebih besar pada individu yang memiliki disposisi harapan yang sedang dan tinggi, dibanding dengan individu yang memiliki disposisi harapan yang rendah. Oleh karena itu, efek sabar terhadap resiliensi diperkuat dengan disposisi harapan yang tinggi dapat dibuktikan, sehingga hipotesis yang diajukan dapat diterima. 
Tabel 1

Model Moderasi Disposisi Harapan

\begin{tabular}{rccc}
\hline & Coeff & $\boldsymbol{S E}$ & $\boldsymbol{t}$ \\
\hline Intercept & $70,0288^{* *}$ &, 6015 & $116,429^{* *}$ \\
Harapan (M) &, $6357^{* *}$ &, 0927 & $6,8609^{* *}$ \\
Sabar (X) &, $3544^{*}$ &, 1459 & $2,4296^{*}$ \\
Sabar x Harapan &, $0499^{*}$ &, 0193 & $2,5833^{*}$ \\
\hline
\end{tabular}

${ }^{* *} p<.001 ;{ }^{*} \mathrm{p}<.05$

$\mathrm{R}^{2}=, 2987 ; M S E=66,3159 ; F(3,320)=36,5813$

\section{Tabel 2}

Model Moderasi Disposisi Harapan

\begin{tabular}{lccc}
\hline \multirow{2}{*}{ Sabar } & \multicolumn{3}{c}{ Harapan } \\
\cline { 2 - 4 } & (1 SD Below) & (Mean) & (1 SD Above) \\
\hline (1 SD Below) & 71,1713 & 68,3616 & 65,5518 \\
(Mean) & 74,4841 & 70,0288 & 65,5734 \\
(1 SD Above) & 77,7969 & 71,696 & 65,5951 \\
& & & \\
\hline & Harapan Rendah & Harapan Sedang & Harapan Tinggi \\
Harapan Rendah & 71,1713 & 68,3616 & 65,5518 \\
Harapan Sedang & 74,4841 & 70,0288 & 65,5734 \\
Harapan Tinggi & 77,7969 & 71,696 & 65,5951 \\
\hline
\end{tabular}

\section{Gambar 1}

Grafik Disposisi Harapan pada Efek Kesabaran terhadap Resiliensi

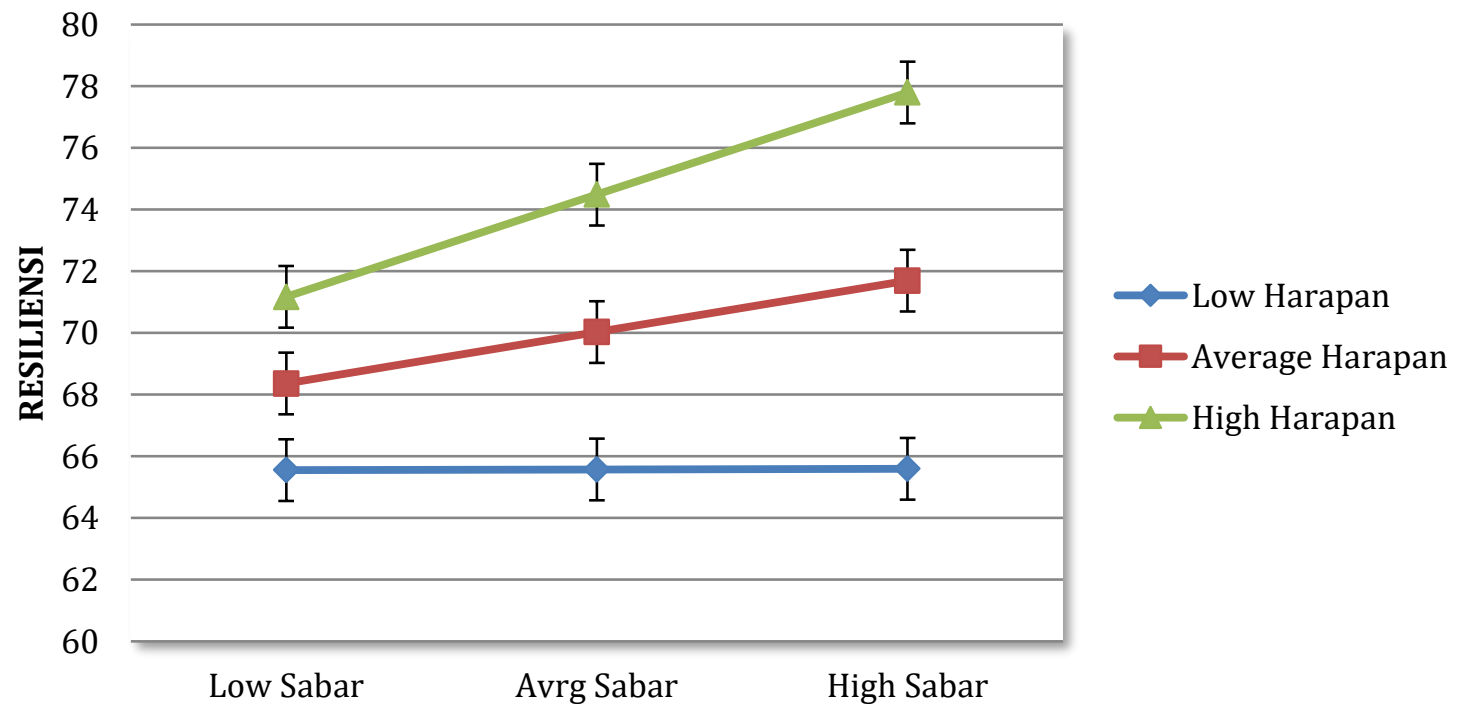


Tabel 3

Koefisien Efek Disposisi Harapan

\begin{tabular}{|c|c|c|c|c|c|}
\hline \multirow[t]{2}{*}{ Predictor } & \multirow[t]{2}{*}{ Moderator } & \multicolumn{4}{|c|}{$\begin{array}{c}\text { Resiliensi } \\
\end{array}$} \\
\hline & & Affect & Std. Error & $\mathrm{T}$ & $\mathrm{P}$ \\
\hline \multirow[t]{3}{*}{ Sabar } & HarapanHigh & ,7042 & 2195 & 3,9975 & ,0000 \\
\hline & Harapan & ,3544 & , 1459 & 2,4296 & ,0159 \\
\hline & Harapan $_{\text {Low }}$ & ,0046 & .1621 & ,0001 & ,9833 \\
\hline
\end{tabular}

\section{Diskusi}

Penelitian ini telah membuktikan bahwa disposisi harapan memiliki peran sebagai pengontrol kekuatan efek kesabaran terhadap resiliensi. Di antara disposisi harapan diuji, disposisi harapan tinggi lebih signifikan dalam memperkuat efek positif kesabaran terhadap resiliensi dibandingkan dengan disposisi harapan sedang. Sedangkan, disposisi harapan rendah tidak signifikan dalam memperkuat efek kesabaran terhadap resiliensi. Hal ini menunjukkan bahwa semakin tinggi disposisi harapan maka akan semakin memperkuat efek kesabaran terhadap resiliensi.

Disposisi harapan yang tinggi dihasilkan dari berbagai konsep yang terkait dengan variabel harapan itu sendiri. Konsep yang dapat menjelaskan proses peningkatan harapan pada efek kesabaran terhadap resiliensi yaitu motivasi mencapai tujuan. Konsep tersebut saling terkait dan bagian tidak terlepas dari ketiga variabel yang diuji dalam penelitian ini. Keterkaitan konsep tersebut dapat menjelaskan peran disposisi harapan tinggi pada efek kesabaran terhadap resiliensi.

Motivasi untuk mencapai tujuan merupakan bagian dari unsur harapan dan dapat mendorong individu untuk memiliki harapan yang tinggi (Nelissen, 2017). Motivasi memberikan energi untuk terus berusaha menghasilkan berbagai alternatif solusi (Lopez \& Snyder, 2003) dan berupaya untuk merencanakan secara matang demi tercapainya tujuan yang diinginkan (Ong, Standiford, \& Dishpande, 2017). Individu yang memiliki harapan yang tinggi akan lebih siap untuk menghadapi situasi sulit dan termotivasi untuk mencapai tujuan dengan berbagai macam cara (Cheavens \& Ritschel, 2014), dibandingkan dengan individu yang memiliki harapan yang rendah.

Disposisi harapan tinggi juga mendorong individu untuk menetapkan tujuan yang lebih sulit (Snyder, 2000) dengan mereduksi tingkat kecemasan (Rahimipour, Shahgholian, dan Yazdani, 2015) sehingga individu dengan harapan yang tinggi tidak mudah menyerah ketika menghadapi situasi yang sulit. Individu dengan disposisi harapan tinggi memiliki pandangan positif terhadap kesulitan dalam menghadapi stres dengan lebih baik sehingga terdorong untuk optimis dalam menghadapi tantangan dan berorientasi terhadap pemecahan masalah (Brooks \& Goldstein, 2009).

Begitu kuatnya peran disposisi harapan yang tinggi dalam memperkuat efek kesabaran terhadap resiliensi, berbeda dengan peran disposisi harapan yang rendah. Individu yang memiliki disposisi harapan yang rendah cenderung menunjukkan motivasi yang rendah pula untuk mencapai tujuan yang diinginkan, tidak siap dalam menghadapi situasi sulit dan menetapkan tujuan yang mudah sehingga menganggap situasi sulit sebagai alasan untuk merasa kalah. Meskipun individu memiliki kesabaran yang dapat memunculkan perilaku resiliensi, tetapi harapan yang rendah tidak signifikan dalam meningkatkan efek tersebut.

Penelitian ini juga telah membuktikan bahwa kesabaran dapat memberikan efek positif signifikan terhadap resiliensi. Keterkaitan antara kesabaran dengan resiliensi sebagai bagian yang tidak terpisahkan dari konsep resiliensi dan saling melengkapi dalam mempengaruhi suatu variabel (Bajaj \& Pande, 2016). Resiliensi mengandung konsep yang jelas tentang orientasi perilaku yang dikenal sebagai goals atau tujuan. Tanpa adanya tujuan, seseorang tidak mungkin menjadi pribadi yang resilien (Brooks \& Goldstein, 2009).

Individu akan berupaya mencapai tujuan dengan menerapkan berbagai macam strategi sehingga dapat keluar dari kondisi sulit. Upaya dalam mencapai tujuan yang tergambar jelas dalam resiliensi ini, membutuhkan variabel yang dapat menopang tercapainya tujuan. Hasil penelitian ini menunjukkan bahwa variabel kesabaran mengambil peranan tersebut, karena 
konsep kesabaran tidak terlepas dari pencapaian tujuan (El Hafiz, Mundzir, Rozi, \& Pratiwi, 2015).

Keterkaitan antara kesabaran dengan resiliensi diperkuat dengan konsep kayakinan dan motivasi (Cerasoli \& Ford, 2014) yang dibutuhkan untuk tercapainya tujuan. Keyakinan akan tercapainya tujuan dapat memberikan energi untuk terus bersemangat, optimis dan pantang menyerah (El Hafiz, Mundzir, Rozi, \& Pratiwi, 2015). Keyakinan dan semangat inilah yang dapat mendorong munculnya kesabaran dan pada akhirnya akan berefek pada munculnya resiliensi (Maslahah, 2011).

Kontrol diri juga memberikan sumbangan teoritis dalam memperkuat keterkaitan efek kesabaran terhadap resiliensi. Keterkaitan tersebut dapat dilihat dari Kesesuaian konsep kesabaran dengan resiliensi (Subandi, 2011), kontrol diri merupakan salahsatu komponen dari resiliensi (Connor \& Davidson, 2003), termasuk bagian yang tak terpisahkan dari resiliensi (Brooks \& Goldstein, 2009) dan telah terbukti memiliki korelasi yang positif dengan kesabaran (Usman, 2016).

Keterkaitan secara teoritis antar konsep kesabaran dengan resiliensi dengan mengelaborasikan aspek tujuan dan kontrol diri, mengarahkan penelitian selanjutnya untuk menjadikan tujuan dan kontrol diri sebagai variabel mediator antara kesabaran dengan resiliensi. Eksplorasi yang mendalam tentang variabel yang dipertimbangkan sebagai variabel mediator akan memperkaya pemahaman tentang keterkaitan antara variabel kesabaran dengan resiliensi, baik sebagai mediasi penuh atau sebagian.

Selain kontrol diri, motivasi dalam mencapai tujuan perlu dipertimbangkan untuk mengeksplorasi lebih dalam tentang efek harapan terhadap resiliensi. Dalam hal tersebut, penelitian ini telah membuktikan bahwa harapan memberikan efek positif signifikan terhadap resiliensi. Pendalaman tentang motivasi untuk mencapai tujuan akan memberikan kontribusi pengembangan teoritis dalam menjelaskan keterkaitan harapan dengan resiliensi yang tergantung pada variabel motivasi mencapai tujuan.

\section{Kesimpulan}

Penelitian ini bertujuan untuk membuktikan peran moderasi harapan pada efek kesabaran terhadap resiliensi dan menguji kekuatan efek kesabaran terhadap resiliensi tergantung pada disposisi harapan yang tinggi, sedang, dan rendah. Kesimpulan dalam penelitian ini adalah efek sabar terhadap resiliensi diperkuat dengan disposisi harapan yang tinggi. Individu yang memiliki harapan yang tinggi dan sedang, secara signifikan memperkuat efek kesabaran terhadap resiliensi. Sedangkan individu yang memiliki harapan yang rendah, tidak signifikan memperkuat efek kesabaran terhadap resiliensi.

\section{Kelemahan dan Saran}

Sebagai saran bagi penelitian lanjutan maupun langkah-langkah yang cukup bermakna untuk meningkatkan resiliensi individu dengan menanamkan kesabaran dalam diri dan meningkatkan harapan yang dimiliki oleh individu untuk memperbesar peluang terbentuknya perilaku resiliensi, dapat disampaikan sebagai berikut:

1. Hendaknya individu meningkatkan perilakuperilaku yang menggambarkan aspek kesabaran, yaitu optimis dalam menghadapi segala permasalahan, pantang menyerah dalam memecahkan masalah, semangat mencari informasi, memiliki semangat untuk senantiasa mencari solusi, konsisten dalam upaya pemecahan masalah, dan tidak mudah mengeluh saat menghadapi masalah sehingga peluang terbentuknya resiliensi dapat ditingkatkan.

2. Instrumen yang digunakan untuk mengukur kesabaran memiliki internal konsisensi yang beragam pada penelitian-penelitian sebelumnya. Sebaiknya, penelitian selanjutnya mempertimbangkan untuk menggunakan alat ukur kesabaran lain, seperti alat ukur kesabaran versi kedua yang disusun oleh El Hafiz, Mundzir, Rozi, dan Pratiwi (2015) dan skala kesabaran yang disusun oleh Brockhoff dkk., (2015).

3. Hendaknya individu memiliki keyakinan dan semangat untuk melakukan berbagai cara dalam mencapai tujuan sehingga keyakinan dan semangat dapat menjadi pendorong yang kuat dan positif untuk mencapai resiliensi.

4. Jika individu mengalami permasalahan dalam menjalani hidup, maka diharapkan memiliki resiliensi yang bersumber dari kesabaran dan harapan. Efek munculnya resiliensi akan lebih kuat jika individu memiliki kesabaran dan harapan pada disposisi tinggi dan sedang.

Acknowledgment: Peneliti mengucapkan terima kasih kepada Anggun yang telah membantu dalam penyebaran kuesioner dan penentuan alat ukur.

\section{Daftar Pustaka}

Al-Jauziyah, \& Ibn, A.-Q. (2006). Kemuliaan sabar 
dan keagungan syukur. Mitra Pustaka.

Al Eid, N. A., Alqahtani, M. M. J., Marwa, K., Arnout, B. A., Alswailem, H. S., \& Al Toaimi, A. A. (2020). Religiosity, Psychological Resilience, and Mental Health Among Breast Cancer Patients in Kingdom of Saudi Arabia. Breast Cancer: Basic and Clinical Research. https://doi.org/10.1177/117822342090 3054

Azzahra, F. (2017). Pengaruh Resiliensi Terhadap Distres Psikologis Pada Mahasiswa. Jurnal Ilmiah Psikologi Terapan, 5(1), 80-96. https://doi.org/https://doi.org/10.22219 /jipt.v5i1.3883

Bajaj, B., \& Pande, N. (2016). Mediating role of resilience in the impact of mindfulness on life satisfaction and affect as indices of subjective well-being. Personality and Individual Differences. https://doi.org/10.1016/j.paid.2015.09.0 05

Brockhoff, K., Margolin, M., \& Weber, J. (2015). Towards Empirically Measuring Patience. Universal Journal of Management. https://doi.org/10.13189/ujm.2015.0305 01

Brooks, R. \& Goldstein, S. (2009). Rahasia Tahan Banting. Jakarta. Serambi

Bonanno, G. A., Galea, S., Bucciarelli, A., \& Vlahov, D. (2007). What predicts psychological resilience after disaster? The role of demographics, resources, and life stress. Journal of consulting and clinical psychology, 75(5), 671. https://doi.org/10.1037/0022006X.75.5.671

Cerasoli, C. P., \& Ford, M. T. (2014). Intrinsic motivation, performance, and the mediating role of mastery goal orientation: A test of self-determination theory. Journal of Psychology: Interdisciplinary and Applied.

https://doi.org/10.1080/00223980.2013. 783778

Cheavens, J. S., \& Ritschel, L. A. (2014). Hope theory. In M. M. Tugade, M. N. Shiota, \& L. D. Kirby (Eds.), Handbook of positive emotions (pp. 396-410). The Guilford Press.

https://psycnet.apa.org/record/201405880-023

Clanton, J., Fawley, R., Haller, N., Daley, T., Porter, J., Paranjape, C., \& Bonilla, H. (2014). Patience is a Virtue: An Argument for Delayed Surgical Intervention in Fulminant Clostridium difficile Colitis. The American Surgeon, 80(6), 614-619. https://doi.org/10.1177/000313481408 000628

Connor, K. M., \& Davidson, J. R. T. (2003). Development of a new resilience scale: The Connor-Davidson Resilience Scale (CDRISC). Depression and Anxiety, 18(2), 7682. https://doi.org/10.1002/da.10113

El Hafiz, S., Mundzir, I., Rozi, F., \& Pratiwi, L. (2015). Pergeseran Makna Sabar dalam Bahasa Indonesia. Jurnal Ilmiah Penelitian Psikologi: Kajian Empiris Dan Non Empiris, 1(1), 33-38. https://jipp.uhamka.ac.id/index.php jipp/article/view/4

Faith, M. A., Mayes, S., Pratt, C. D., \& Carter, C. (2019). Improvements in Hope and Beliefs about Illness Following a Summer Camp for Youth with Chronic Illnesses. Journal of Pediatric Nursing, 44, 56-62. https://doi.org/10.1016/j.pedn.2018.10.0 16

Grotberg, E. (1995). Early Childhood Development: Practice and Reflections Number 8 A guide to promoting resilience in children: strengthening the human spirit The International Resilience Project Bernard van Leer Foundation. https://bibalex.org/baifa/attachment/do cuments/115519.pdf

Hassani, P., Izadi-Avanji, F.-S., Rakhshan, M., \& Majd, H. A. (2017). A phenomenological study on resilience of the elderly suffering from chronic disease: a qualitative study. Psychology Research and Behavior Management, Volume 10, 59-67. https://doi.org/10.2147/PRBM.S121336

Hayes, A. F. (2013). Introduction to mediation, moderation, and conditional process analysis: A regression-based approach. PsycNET. Guilford Press. https://psycnet.apa.org/record/201321121-000

Hirsch, J. K., Sirois, F. M., \& Lyness, J. M. (2011). Functional impairment and depressive symptoms in older adults: Mitigating effects of hope. British Journal of Health Psychology, 16(4), 744-760. https://doi.org/10.1111/j.20448287.2010.02012.x

Hu, T., Zhang, D., \& Wang, J. (2015). A metaanalysis of the trait resilience and mental health. Personality and Individual Differences.

https://doi.org/10.1016/j.paid.2014.11.0 39

Iacoviello, B. M., \& Charney, D. S. (2019). Cognitive and behavioral components of resilience to stress. In Stress Resilience: Molecular and Behavioral Aspects (pp. 23- 
31).

Elsevier.

https://doi.org/10.1016/B978-0-12-

813983-7.00002-1

Jenaabadi, H., \& Mir, F. (2019). Role of Trust in God and Resilience in Hope for Life of Hemodialysis Patients. Health, Spirituality and Medical Ethics, 6(1), 33-38. https://doi.org/10.29252/jhsme.6.1.33

Kim, J. H., Hawley, C. E., Gonzalez, R., Vo, A. K., Barbir, L. A., McMahon, B. T., Lee, D.-H., Lee, J. H., \& Lee, Y. W. (2018). Resilience From a Virtue Perspective. Rehabilitation Counseling Bulletin, 61(4), 195-204. https://doi.org/10.1177/003435521771 4995

Li, M. Y., Yang, Y. L., Liu, L., \& Wang, L. (2016). Effects of social support, hope and resilience on quality of life among Chinese bladder cancer patients: A cross-sectional study. Health and Quality of Life Outcomes, 14(1), 73. https://doi.org/10.1186/s12955-0160481-z

Lopez, S. J., \& Snyder, C. R. (2003). Positive Psychological Assessment: A Handbook of Models and Measures. American Psychological Association. https://www.apa.org/pubs/books/43160 04

Mahedy, L., Harold, G. T., Maughan, B., Gardner, F., Araya, R., Bevan Jones, R., Hammerton, G., Sellers, R., Thapar, A., \& Collishaw, S. (2018). Resilience in high-risk adolescents of mothers with recurrent depressive disorder: The contribution of fathers. Journal of Adolescence. https://doi.org/10.1016/j.adolescence.20 18.03.016

Maslahah, U. (2011). EFEKTIVITAS PELATIHAN SABAR UNTUK MENINGKATKAN RESILIENSI PADA WANITA YANG MENGALAMI PERCERAIAN. Skripsi. Yogyakarta. http://digilib.uinsuka.ac.id/6318/

Nelissen, R. M. A. (2017). The motivational properties of hope in goal striving. Cognition and Emotion, 31(2), 225-237. https://doi.org/10.1080/02699931.2015. 1095165

Newman, R. (2005). APA's resilience initiative. In Professional Psychology: Research and Practice. https://doi.org/10.1037/07357028.36.3.227

Oldfield, J., Stevenson, A., Ortiz, E., \& Haley, B. (2018). Promoting or suppressing resilience to mental health outcomes in at risk young people: The role of parental and peer attachment and school connectedness. Journal of Adolescence. https://doi.org/10.1016/j.adolescence.20 18.01.002

Ong, A. D., Standiford, T., \& Deshpande, S. (2017). The Oxford Handbook of Hope. In M. W. Gallagher \& S. J. Lopez (Eds.), The Oxford handbook of hope. (Vol. 1). Oxford University Press. https://doi.org/10.1093/oxfordhb/9780 199399314.001.0001

Pacico, J. C., Bastianello, M. R., Zanon, C., \& Hutz, C. S. (2013). Adaptation and validation of the dispositional hope scale for adolescents. Psicologia: Reflexao e Critica, $26(3)$ 488-492. https://doi.org/10.1590/S010279722013000300008

Perez-Melo, S., \& Kibria, B. M. G. (2020). On Some Test Statistics for Testing the Regression Coefficients in Presence of Multicollinearity: A Simulation Study. Stats, 3(1), 40-55. https://doi.org/10.3390/stats3010005

Rahimipour, M., Shahgholian, N., \& Yazdani, M. (2015). Effect of hope therapy on depression, anxiety, and stress among the patients undergoing hemodialysis. Iranian Journal of Nursing and Midwifery Research, 20(6), 694. https://doi.org/10.4103/17359066.170007

Simeon, D., Yehuda, R., Cunill, R., Knutelska, M., Putnam, F. W., \& Smith, L. M. (2007). Factors associated with resilience in healthy

adults. Psychoneuroendocrinology, 32(8-

10), 1149-1152. https://doi.org/10.1016/j.psyneuen.2007 .08 .005

Snyder, C. R. (2000). Handbook of Hope: Theory, Measurement, and Applications. Academic Press.

https://www.booksamillion.com/p/Hand book-Hope/C-RichardSnyder/9780126540505\#overview

Solano, J. P. C., Da Silva, A. G., Soares, I. A., Ashmawi, H. A., \& Vieira, J. E. (2016). Resilience and hope during advanced disease: A pilot study with metastatic colorectal cancer patients. BMC Palliative Care, 15(1), 70. https://doi.org/10.1186/s12904-0160139-y

Subandi. (2011). Sabar: Sebuah Konsep Psikologi. Jurnal Psikologi, 38(2), 215-227. https://jurnal.ugm.ac.id/jpsi/article/view /7654

Usman. (2016). Pengaruh religiusitas dan sabar terhadap kontrol diri pada remaja yang tidak berpacaran. Skripsi tidak dipublikasikan. Jakarta. 